\title{
International Public Opinion on China’s Climate Change Policies
}

\author{
Valerie Victoria Benguiat y Gomez \\ UNEP-TONGJI Institute of Environment for Sustainable Development, Tongji University, Shanghai, China \\ Email: vbenguiat@gmail.com
}

Received September $3^{\text {rd }}$, 2013; revised October $7^{\text {th }}$, 2013; accepted October $15^{\text {th }}, 2013$

Copyright (c) 2013 Valerie Victoria Benguiat y Gomez. This is an open access article distributed under the Creative Commons Attribution License, which permits unrestricted use, distribution, and reproduction in any medium, provided the original work is properly cited.

\begin{abstract}
With the emergence of a global public sphere and the revolution of global media, international public opinion has gained an intrinsic importance for effective multilateral cooperation. Global governance initiatives are subject to international public opinion, and climate change is the single most important global governance issue of our time. Tackling climate change requires a fundamental transformation of the global economy, with an emphasis on sustainable development. Due to its political and economic weight, China can push forward UN climate change negotiations, and can do so without compromising its national development goals (China's National Climate Change Programme, 2007). China's national policies are beyond what is required from developing nations, but international public opinion often perceives a different message. This paper holds that a national branding strategy will help convey China's current efforts, allowing a better understanding among nations in order to break the climate change negotiations deadlock. This research merged perception analysis and public opinion surveys with mass media qualitative and quantitative analysis to gain a full insight into what the international climate change decisionmakers, opinion-leaders and general public think about China's position at the UNFCCC negotiations. As seen in the findings of the present research, the climate of opinion is unfavorable to China. Overall, the results show that China is perceived as a negative influence in the negotiations. China's climate change efforts are being overlooked by international public opinion. But the reason lies in China's current discourse, where climate change and the environment are always downplayed by the right to develop (D’Hooghe, 2011). According to China's 12th Five Year Plan, the new path for the country is marked by its commitment to achieve growth through low carbon development, with a strong focus on addressing climate change and energy challenges (Shealy \& Dorian, 2007). The results of this study show that the positive intentions and actions of the Chinese government aren't being accurately perceived by public opinion. The empirical findings in this study provide a new understanding of one specific part of the overall image that the world has about China. Whilst this study did not confirm unequivocally that international public opinion directly determines the outcomes of international negotiations and foreign policy, it did partially substantiate the concept that there's a correlation between China's public declarations and actions, the negotiators declarations to the press, press coverage in general, the attitude of experts towards China, and the attitudes and perceptions of uninformed public towards China. The study concludes that China requires a country rebranding strategy, and presents solid data as to which areas China has to tackle. This paper can be a working base for the national branding strategy, but by no means intends to be a complete evaluation of China's brand.
\end{abstract}

Keywords: Climate Change; Public Opinion; Perception Analysis; International Negotiations

\section{Introduction}

Climate change is not only a scientific and technical problem but also an economic and geopolitical issue. Currently, climate change negotiations are the means through which governments are trying to address dubious success with an unequivocally global issue (Pachauri et al., 2007). A poor understanding among nations has obstructed climate change negotiations and the world has been unable to reach a binding agreement that will get the wheels turning.

Due to its intrinsic weight in UNFCCC negotiations, the current research focuses on China, and on public opinion regarding China's perceived climate change actions. The current research is based on the informed assumption that China can unlock the negotiations, and can push them out of the stagnant phase they have fallen into. It's China's turn to shine as the mobilizing force it can become (Harris, 2010).

As a background, it is important to know that China first became involved in international discussions on climate change in the 1980s when it collaborated with the United States to study the impacts of $\mathrm{CO}_{2}$ emissions, thus beginning a process of growing Chinese involvement and interest in climate diplomacy and its impact on international relations, economics, and the environment (Heggelund, 2007). China's climate change diplomacy became more proactive in the 1990s when it joined with other developing countries to influence the negotiations of the 1992 Framework Convention on Climate and the 1997 Kyoto Protocol (Harris, 2011).

Now, China continues this commitment started so long ago. China's latest climate change policies are based on: 1) ad- 
dressing climate change within the broader framework of the country's national sustainable development strategy; 2) following the principle of common but differentiated responsibilities (CBDR); 3) addressing both climate change mitigation and adaptation; 4) integrating climate change policies with economic development plans (Wang \& Watson, 2009); 5) developing and receiving new technologies for effectively mitigating and adapting to climate change; and 6) participating actively and extensively in international cooperation on climate change.

However, developed countries have been pushing China into taking more aggressive actions against climate change, and above all, to allow monitoring of those actions, a petition that China blatantly refused for a long time. China has strongly opposed to proposals requiring independent monitoring, review and verification (MRV) of its pledge to reduce the carbon intensity of its economy by $40-45$ percent by 2020 . According to Paul G. Harris, "these sorts of demands have run up against China's profound sense of grievance generally vis-a-vis the outside world for 20th-century intervention in Chinese affairs” (Harris, 2011), especially the ones that contradict China's idea that only developed countries are to blame for climate change.

Currently, there is limited research focused on the pressure groups involved in climate change international negotiations. There has been little discussion about the role of public opinion on the process and outcomes of climate change negotiations. Furthermore, there has been no research on how public opinion regarding a specific country can affect how others negotiate with said country; in this case, with China.

The purpose of the current study was to determine and draw recommendations to rebrand China's climate change international discourse, based on the state of international public opinion on China's climate change policies. Based on media analysis, interviews with experts and collecting information from general public, this research explored what people think of China and why.

The author aims to generate knowledge that will help more clearly frame a communications and PR strategy that can enable China to better portray its unprecedented environmental efforts, and provide insights for Chinese policy and decisionmakers into the relevance of international public opinion.

\section{Scope}

The geographic scope of the thesis is limited only by language barriers. The study required no other fieldwork than interviews and surveys. The surveys and interviews have been collected based on language ability of the researcher and Internet access of the interviewees.

Given the multidisciplinary nature of an international public opinion analysis, it would be difficult to exhaust the topic in one paper, even for a topic as concrete as China's climate change policies. To generate reliable and replicable results, this thesis limits itself to assessing the current climate of opinion of countries, which participate in UNFCCC negotiations, and only on the recipients' side of China's climate change messagesboth explicit and implicit.

\section{Methodology}

For the methodology, this research merged perception analysis (derived from psychology and most commonly used in marketing and public relations) (Galindo, 1998) and public opinion analysis (belongs to social sciences, most commonly used for political purposes) with mass media analysis (AlvarezGayou Alvarez, 2003) to gain a full insight into what the international climate change decision-makers, opinion-leaders and general public think about China's position at the UNFCCC negotiations.

\section{Public Opinion}

Public opinion is defined as the prevailing and widespread belief of the majority of people in a society about a given subject or issue (D'Adamo, Beaudoux, \& Freidenberg, 2007). The tools for analysing public opinion are questionnaires, interviews, focus groups and media analysis (Boeije, 2010). Perception and brand analyses also rely on these tools, and form part of the non-political part of public opinion.

A perception study is a survey, or series of surveys, that assesses the market's opinions on a target, in the case of this research, the international opinions on China (Siniscalco \& Auriat, 2005). A perception analysis provides a better understanding of what matters most to the audience. What do people care about? What are the current priorities of our audience? Are we communicating our messages correctly? What do people think about our brand? And as a consequence, it allows the communicators to better design their messages. How can we change people's mind? How can we influence people’s opinion about our brand (in this case, about China)?

\section{Country Branding}

A brand is the idea or image of a specific product or service that consumers connect with, by identifying the name, logo, slogan, or design of the company who owns the idea or image (Erhardt, 2012). Countries can be seen like complex ideological products that also have a brand. Every country has its own reputation, brand image, brand identity, and brand value (Forbes, 2010). The people, tourism, culture, governance, economic strategies (exports, investment and immigration), contribute to the country's image. The ultimate objective of knowing and handling a country's brand is to reduce the perception gap between the brand identity (projected by the country, what the country wants to say) and brand image perceived by the rest of the world (Frost, 2004). In this case, reducing the gap between what China wants to communicate (We are a sustainable country, committed to ambitious emission reductions) and what other countries are perceiving (China is the biggest polluter in the world, unwilling to commit to emission reductions).

Both the brand and public opinion are reflected in mass media. Media content analysis has both qualitative and quantitative approaches (Niño-Zarazúa, 2012). In the present research, both will be taken into consideration. Early experts in communication tended to favour the quantitative approach, like Berelson (Busha \& Harter, 1980), who described media content analysis as a "research technique for the objective, systematic and quantitative description of the manifest content of communication” (Macnamara, 2005).

\section{Media Analysis}

Contemporary experts favour an analysis that includes quantitative and qualitative methods. Qualitative analysis studies the meaning — or possible meanings — of the text in question, the likely interpretations of the audience, what is the meaning of words in a given context, the subtexts given by editorial line, 
and how different media communicate with their audiences (Krippendorff, 2004). “Accordingly, qualitative content analysis relies heavily on researcher 'readings' and interpretation of media texts. This intensive and time-consuming focus is one of the reasons that much qualitative content analysis has involved small samples of media content and been criticized by some researchers as unscientific and unreliable” (Macnamara, 2005).

While qualitative analysis does rely on the interpretation of the researcher, for the analysis to be valid the researcher in question must be a trained professional to minimize the risk of misreading. The finality of media content analysis is to output data that is objective, susceptible to measuring and verification, that can be explained qualitatively and quantitatively, and susceptible to generalization to facilitate an objective view of the fact.

The quantitative treatment of symbolic materials requires a clear specification of the measuring unit. In the present research, the quantitative analysis referred to the number of mentions (incidences) of China in an article per media per tone (positive, neutral, negative).

There's a first step in sampling, which constitutes gathering the complete corpus of media to be analysed. This universe of articles was the same for both quantitative and qualitative analyses. "Sampling for media content analysis comprises three steps (Newbold, 2002):

1) Selection of media forms (i.e. newspapers, magazines, radio, TV, film) and genre (news, current affairs, drama, soap opera, documentary, and so on);

2) Selection of issues or dates (the period);

3) Sampling of relevant content from within those media” (Macnamara, 2005).

The media form in the present research is online news. The dates range from September 2009 to December 2012. The topics considered for the content analysis were: China and climate change and/or COP15, COP16, COP17, COP18 and/or UNFCCC.

Even after setting aside from the universe of online articles from 2009 to 2012 the ones that are relevant for this research, the corpus is too extensive. Selecting all units that contain the key topics (a census) would provide the greatest possible representation of the sampling frame. Yet, as it was not feasible due to budget and time constraints, a sample of media within this universe was selected as follows:

- Purposive such as selecting all articles from key media (and not from less important media). In this case, the media analysed was BBC, CNN, The Guardian, The New York Times, The Washington Post, Reuters, Al Jazeera and AFP;

- Quota such as selecting a proportion of articles from each of several regions or areas (geographic, demographic, psychographic, or subject category). Same media as above applies, given that agencies such as Reuters and AFP cover most regions and feed most widespread media;

- Stratified composite samples constructed by randomly selecting units for analysis (articles or ads) from certain days or weeks over a period. Within the same media as above, the units selected were randomly selected close to the dates of international negotiations (Macnamara, 2005).

\section{Results}

Based on the limited data available, it appears that public concern has been growing since 2009 about China's role in climate change negotiations (Howes, 2009). It's clear that China is regarded as a key negotiator, a force that can either stall or push forward binding agreements. Its increasing economic power has played an important role at putting China in the centre of every international negotiation. Climate change illustrates how the geopolitical zones are currently divided. Without denying the importance of the EU block, or India and Brazil, China and the US hold hostage the centre of the stage (Minas, 2010). UNFCCC negotiations haven't had substantial outcomes due to the fact that these two countries have been unable and unwilling to compromise.

Either of them can represent a tipping point in the history of humanity, for better or for worse. Due to this fact, the press and the public opinion have their eyes set on China. The lack of concrete publicized results has earned China a bad name in international negotiations.

As seen in the findings of the present research, the climate of opinion is unfavourable to China. The preponderant worldview of China is negative. But it's not exclusively tied to China's climate change policies and the country's performance during the negotiations (Kriss, Loewenstein, Wang, \& Weber, 2011). The animosity spreads beyond. Lack of transparency, corruption, growing military power, advantageous commercial activities and human rights issues also preoccupy the public, and affect the country's brand and the people's perceptions.

A poll conducted by GlobeScan/PIPA in 2011 revealed that China becoming more powerful economically was perceived as a bad thing according to a number of China's key trading partners-and especially in G7 countries (Ruppel, Grimm \& Van Wyk, 2011). This can be a strong reason behind the apparent international animosity. China has affected very solid markets — such as the EU, US, Brazil, Mexico-and has received antidumping levies, due to what is perceived as unfair trade practices (BBC, 2011).

That's the image that people have in their minds about China: the giant, the superpower, the fastest growing economy, devouring local economies with its cheaper products, being the cause of unemployment and crisis. Even if this isn't accurate, the sentiment remains (AFP, 2010, 2012).

The findings of the present research showed that as the fastest growing economy in the world and the biggest polluter, everyone expects a lot of China. When China has failed to meet international expectations, its image has suffered the blow in the proportions of its size and its intrinsic importance in today's politics. Despite the fact that China is putting forward the best foot, outlining ambitious policies and making efforts to reduce the rate of its emissions, to invest in cleaner energies and in reforestation, the findings of the present research showed that people and media expect more (Al Jazeera, 2012).

The results of the survey showed that the public has a stereotyped image of China. In the public opinion survey that was applied following the methodology and type of questions of the Pew Research Center (Chandler, Schaeffer, \& Zhou, 2002), $50.18 \%$ of the people surveyed disapproved of the way China is handling its foreign policy, and $37.36 \%$ somewhat disapproved of how China is handling climate change. 15.02\% thought that China should play the same role than developed countries in climate change negotiations, while only $10.26 \%$ thought China deserves the same treatment as developing nations. Still, 53.11\% thought that climate change is a major concern for China, but $49.08 \%$ thought that China doesn't consider the well being of other countries' interests when outlining for- 
eign policies. $41.39 \%$ of the surveyed thought that China is obstructing climate change negotiations, against $20.88 \%$ who thought China is being proactive at the negotiations.

A randomized sample of articles from 2009 to 2012 (see all articles in the references section of this article) from the media outlets defined in the methodology was analysed qualitatively to determine the messages that during this period were published regarding China in relation to climate change. As seen also in the quantitative analysis, the results were preponderantly negative or neutral, and in less extent, positive towards China. During 2009 the media took a strong position against China due to the Copenhagen incident with the US, and due to China's too overt refusal to a binding agreement (Freeman \& Holslag, 2009). The absence of Chinese high representatives in Copenhagen's Heads of State meeting was a hard blow on China's image. The international media took this incident as a sign of contempt, as an attempt to boycott and stall the negotiations, and as an open unwillingness to find a middle ground. The 2009 Copenhagen climate-change summit was covered extensively in the media; each article overtly blaming China for what environmentalists consider was a weak outcome.

In 2010, the coverage had a vastly neutral or positive tone, and acknowledged China's willingness to reduce emissions and to even make these commitments binding. In the over enthused atmosphere of COP16, what some media outlets failed to report was that China never agreed on international MRV, and that the binding quality of these commitments was only to be pursued in domestic policies, not in an international agreement, which would mean that an external body would enforce and keep track of the reductions. China had declared in several occasions that it would consider this to be a violation of its sovereignty.

In 2011, however, the coverage tone returned to the negative side of the spectrum as China failed to prove the progress in the reductions that it had promised before. China was also expected to raise the ante, and when it remained conservative in the negotiations, the expectations weren't met and the media scrutinized China's numbers. The fact that China's reporting was suspected to be tainted added to the distrust and enhanced the question "Is China doing what it promised"?

By 2012, the coverage had returned to focus on China's reticence to commit to binding agreements, and despite claims that the country was moving towards a more energy efficient path, the media found the loopholes in the speech, expecting Chinawith its considerable size and developing status-to have achievements to show to the world, and disappointed at China's declarations (see all media articles in the reference section of the present article).

\section{Analysis}

China was constantly portrayed as the one obstacle for the US to be forced to commit to a binding agreement. The CBDR speech that China keeps repeating negotiation after negotiation has been vastly criticized as a defensive and unfair stance. China's commitments to introduce domestic legally binding emission reductions weren't considered ambitious enough, given that the country became the largest polluter, it's one of the fastest growing economies of the world, and receives the same treatment in negotiations as other developing countries the size of Tuvalu.

Overall, the quantitative analysis shows that China appears constantly framed in a negative scenario. The communication from China to the world failed to manage expectations. China lacked charismatic leaders when it needed them the most. China's reputation suffered a hard blow after the Copenhagen incident. There was no visible crisis management, which kept the matter from being closed. The Copenhagen incident was mentioned in articles of 2010 to 2012, portraying China as a conflictive, dismissive, disrespectful country, unwilling to negotiate.

All articles that mention China frame the country as:

- The biggest polluter in the world,

- The fastest growing economy,

- A key negotiator, and

- Unwilling to sign binding agreements.

In the media content analysis, China's discourse has been simplified into a refusal to join a binding agreement. This refusal has been associated with the US refusal to do so as well, and this situation ultimately renders the negotiations completely futile, given that the two most polluting countries in the world cannot reach an understanding. The subtleties of the Chinese discourse are lost in the media, and aren't understood by the general public (This doesn't prevent the public opinion from existing and from having a weight on the negotiating parties. Governments and their representatives are well aware that successfully mitigating or adapting to global warming will require changes in the behaviour of billions of human beings, and will require that all citizens comply with new laws and regulations. Some countries will be able to impose said regulations, but some others like the US cannot do so without public approval.

Regarding the in depth interviews, Dr Milton Reyes said that the roots of China's image might have been planted long time ago and haven't been adequately addressed. Despite China's efforts to rebrand the country-the Beijing Olympics, Expo 2010 (Goodson, 2012) — there's still a latent fear of China. China's commercial and economic hegemony represents a threat to other developing countries that cannot compete with China's productive power, or to more developed countries that are in debt with China. China holds a position of power in the international arena.

As Dr. Zhang Jianyu accurately observes, China's climate change efforts are being overlooked by international public opinion. But the reason lies in China's current discourse, where climate change and the environment are always downplayed by the right to develop. As Dr Milton Reyes said, China's primordial objective is economic growth. Even if domestically China is framing these development and growth as a sustainable, greener growth, the international discourse has kept the right to pollute due to historical responsibility as one of the key arguments of Chinese negotiators. There is no way to frame this argument in a positive way: as the surveys and the content analysis show, CBDR arguments have caused a bad impression, possibly due to the repetitiveness of the discourse (Song \& Woo, 2008).

It can be seen in the quantitative media analysis how the CBDR argument isn't broadly portrayed as negative in 2009, but the negative mentions of China quoting CBDR grow throughout the years, to the point that in 2012 is the topic that has the highest number of negative mentions in media. It's a valid argument that turned against China due to overuse.

\section{Conclusions and Recommendations}

In conclusion, based on the quantitative analysis, the survey, 


\section{BENGUIAT}

the content analysis and the interviews, China is perceived as to be pursuing exclusively national interests, without honouring the alliance that it has-according to China-with other developing countries. China has declared that it's looking after the interests of all developing countries by pushing more developed economies to do more aggressive commitments. Yet, LDCs and AOSIS have pointed fingers at China, denying that China is looking after the smaller members of the developing world. This is a perception also reflected in the findings of the present research.

China ends up isolated by both sides of the equation: developed countries that judge China by its size, its current contributions and its massive GDP, deny China's developing country status and are demanding more from it, branding China as a stalling element of the negotiations. Developing countries also reject China, expressing that the economic giant should do more, and that the CBDR speech should hardly apply to China -vis-à-vis LDCs, for example.

Developed countries are constantly lobbying-and criticising - China for more aggressive actions and to allow external verification of the current emission cuts (Motaal, 2010). However, as expert Paul Harris says, "these kinds of demands run up against China's profound sense of grievance generally vis-à-vis the outside world, and more specifically are counter to its belief that the developed countries are to blame for climate change" (Harris, 2011).

According to China's 12th Five Year Plan, the new path for the country is marked by its commitment to achieve growth through low carbon development, with a strong focus on addressing climate change and energy challenges (Chan \& King, 2011). The results of this study show that the intentions and actions of the Chinese government aren't being perceived as positive or true by public opinion.

Returning to the questions posed at the beginning of this study, it is possible to state that despite the fact that China has made international announcements of its new sustainable approach, the international climate of opinion isn't favourable for China at the time being. It can be concluded that the present international climate of opinion does not reflect accurately China's climate change efforts.

One of the more significant findings to emerge from this study is that uninformed public, specialized interviewees and the press broadly coincide in the general perception of China's climate change actions, and that this perception is broadly negative.

Domestic factors like public opinion constrain foreign policy and international relations. In international negotiations decision-makers strive to reconcile the domestic and international imperatives simultaneously (Leiserowitz, 2007). This is evident during UNFCCC negotiations, where Chinese negotiators hold the economic growth before emission reductions discourse (Lewis, 2007). At the national level, public opinion pressure leaders to embrace policies they favour. In this case, Chinese public wouldn't welcome measures that could harm economic growth. At the international level, governments seek to maximize their degrees of freedom (or preservation of sovereignty) to comply with domestic pressures while at the same time cooperating with other countries and preserve strategic alliances.

The relevance of international public opinion is clearly supported by the current findings. As seen throughout the findings of the research, it's consistent that the actions of Chinese diplomats at COP15 in 2009 turned public opinion against China, and gave pressure groups motive to mistrust China's further proposals. Advisory groups, senates, voters, civil society constitute, create and act accordingly to public opinion.

The results of this research support the idea that China is seen as uncooperative and reticent. Public opinion has branded China as the biggest polluter in the world, that isn't willing to do what is perceived as its fair share to address climate change. The proposed emission cuts that China has put forward are seen as too little compared to the current contributions that are the collateral of the country's unparalleled economic growth.

The empirical findings in this study provide a new understanding of one specific part of the overall image that the world has about China. Whilst this study did not confirm unequivocally that international public opinion directly determines the outcomes of international negotiations and foreign policy, it did partially substantiate the concept that there's a correlation between China's public declarations and actions, the negotiators declarations to the press, press coverage in general, the attitude of experts towards China, and the attitudes and perceptions of uninformed public towards China. It is suggested that the association of these factors is investigated in future studies.

Finally, a number of important limitations need to be considered. First, the budget constraints made it impossible to reach a broader public through direct polls, interviews, or to use the services of a professional poll and survey service. It was also impossible to hold focus groups since there was no budget for travel. Second, also due to budget constraints, not all media could be accessed for analysis, given that some charge a fee to use their websites. Third, like in all perception and public opinion studies, there is room for interpretation and discussion of the results. In the consulted literature, evidence suggests that the impact of public opinion in foreign policy varies from case to case.

With a small sample size, caution must be applied, as the findings might not be transferable to specific non-English speaking countries that weren't considered for the polls and interviews, as clarified in the methodology. Some countries might have a strong positive perception of China's climate change foreign policies. Yet, the effect in the overall negotiations is negligible, given that the biggest actors (US, UK, EU) were considered, polled, interviewed and analysed.

The main weakness of this study was the paucity of country branding and perception analysis literature. To develop strong country rebranding recommendations for a case as complex as China, more research is needed. Future research should therefore concentrate on the investigation of current Chinese international public image strategies, and compared to the results of the present study to unveil the success or failure of said strategies. It would be interesting to assess the effects of Chinese national opinion on China's foreign policies, and on China's design of current climate change policies.

Considerably more work will need to be done to determine what if anything can be done to unlock the current climate change negotiations, but as all policy-making processes, public opinion should be an element to be considered.

The findings of this study have a number of important implications for future practice. China undoubtedly requires a country rebranding strategy. Country branding essentially helps a nation to further the country's influence in the international arena and to further the nation's economic growth by focusing on the nation's identity and brand image. Nation branding is complex, and the public policy of a nation is significant to the 
country's image. The nation's image becomes the reputation of the country.

The current research presents solid data as to which areas China has to tackle, but by no means intends to be a complete evaluation of China's national brand. As shown by this research, China has a bad reputation when it comes to climate change, despite its public policies. China has a bad reputation primarily due to:

- The Copenhagen incident,

- The reticence to allow MRV,

- Refusing binding agreements,

- Becoming the biggest $\mathrm{CO}_{2}$ emitter,

- CBDR discourse, and

- Lack of support to LDCs and AOSIS.

A country rebranding will need to address these topics. Some are impossible to resolve, such as the COP15 incident and becoming the largest polluter in the world. The biggest act on China's part to be able to rebrand itself as sustainable and committed would be to allow MRV. Even if China continued to refuse adhering to binding agreements, external verification would proof the extent of China's NAMAs. China's reticence to allow international inspectors to monitor its internal actions doesn't have solid foundations. China's Vice Minister declared, "There are no problems for transparency. But there will be no MRV internationally because it's a matter of principle” (Hsu \& Kieran, 2009). In this aspect, the recommendation is that China has to be more assertive and step aside from the Bali Action Plan. China must align with developed countries when it comes to MRV, but must ask for clarification as to which institution will perform said verification.

Another strategy would be the proliferation of Chinese NGO's that could lobby on behalf of China. This research shows that NGO's like Oxfam have been more positive regarding China's declarations during UNFCCC negotiations, but the lack of Chinese NGOs have made their repercussions almost negligible to international press. World Wildlife Fund has a strong presence in China and is highly active in low carbon development, and its international origin makes it an efficient vehicle for China's messages if delivered assertively and with verifiable data. WWF's reputation makes it the most reliable in climate change and one of the biggest lobbying groups at UNFCCC negotiations. China will profit vastly from getting WWF on board of its national verification processes. National public opinion, orchestrated around NGO's activities, can convey China's message in a more convincing way than through official speeches.

China has been supporting African countries in sustainability and development projects, but has failed to defend LDCs and AOSIS when it has mattered, at the time of the negotiations. The first thing China needs to incorporate in its official goals and discourse is a pledge to $350 \mathrm{ppm}$ as well as a maximum of 2 degrees Celsius. China's aid to Africa has been primarily economic. As Nick Nutall from UNEP said in an interview to Xinhua news, "The decision (of China) to support 100 projects can assist Africa in economic development and diversification in terms of sectors and wider-employment prospects while assisting towards a more sustainable path. So in terms of fighting poverty, accelerating development and combating climate change, China's announcement to assist Africa is welcome news” (Song \& Zhao, 2011). This is, though, not enough. Since these projects are framed as economic development projects, rather than purely devoted to climate change, they are not seen as altruistic as expected. China is not only expected to put forward financing and technology transfer for these countries, but also to be their voice during UNFCCC negotiations. As a developing country, China is perceived to have abandoned weaker economies in its pursuit of selfish goals.

Finally, China would profit from stepping away the CBDR discourse and assuming its responsibility as the fastest-growing economy in the world. China should openly declare that CBDR is to be applied to smaller economies and less polluting countries, and as an act of good will, and going beyond and above what developing countries are bound to do, China will commit to binding agreements. Historical emissions are part of the past. Now, China is the biggest polluter in the world. Finger pointing and blaming has deeply harmed China's image. Unless China takes action to modify its international image, the possibility of UNFCCC advancing is remote (Climate Connect, 2012).

\section{REFERENCES}

AFP (2010). China would never accept checks at Copenhagen: Official. http://www.smh.com.au/environment/climate-change/china-would-n ever-accept-checks-at-copenhagen-official-20100109-m035.html\#ixz z2N98L2Ppx

AFP (2012). Who's “most to blame” for global warming? http://abcnews.go.com/blogs/technology/2012/07/whos-most-to-bla me-for-global-warming/

Al Jazeera (2012). China timber trade "fuels climate change". http://www.aljazeera.com/indepth/features/2012/12/2012125843915 4302.html

Alvarez-Gayou Jurgenson, J. L. (2003). Cómo hacer investigación cualitativa: Fundamentos y metodología. México: Paidós.

Associated Press (2011). US, China, India block climate-change agreement. http://www.telegram.com/article/20111209/NEWS/111209301/1052

BBC World Service (2011). Global poll reveals rising concern about China's increasing power.

http://www.bbc.co.uk/pressoffice/pressreleases/stories/2011/03_marc h/28/china.shtml

BBC World Service and the Program on International Policy Attitudes (PIPA) (2010). Global views of United States improve while other countries decline.

http://www.worldpublicopinion.org/pipa/pipa/pdf/apr10/BBCViews Apr10_rpt.pdf

Boeije, H. (2010). Analysis in qualitative research. Los Angeles, CA: SAGE.

Busha, C. H., \& Harter, S. P. C. (1980). Analysis in research methods in librarianship-Techniques and interpretation. New York: Academic Press.

Chan, W.-S., Knight, Z., \& Robins, N. (2011). China's rising climate risk: The 20 questions investors need to ask. HSBC Global Research.

Chandler, W., Schaeffer, R., \& Zhou, D. D. (2002). Climate change mitigation in developing countries: Brazil, China, India, Mexico, South Africa and Turkey. Arlington, MA: Pew Center on Global Climate Change.

China Daily (2009). China embraces a new way of thinking about climate change.

http://www.chinadaily.com.cn/bw/2009-11/16/content_8974919.htm

China's National Climate Change Programme (2007). Prepared under the auspices of national development and reform commission People's Republic of China.

http://www.china.org.cn/english/environment/213624.htm

Climate Connect (2012). Doha simplified COP18 summary \& analysis. Climate Connect Limited.

http://knowledge.climate-connect.com/wp-content/uploads/2012/12/ Doha-Simplified-COP18-Summary-Analysis.pdf

CNN (2007). El Primer plan chino contra el cambio climático evita compromisos concretos de reducción de $\mathrm{CO}_{2}$.

http://internacional.elpais.com/internacional/2007/06/04/actualidad/1 
180908008_850215.html

CNN (2010). EU y China se usan de pretexto para no combatir el cambio climático.

http://mexico.cnn.com/planetacnn/2010/10/08/eu-y-china-se-usan-de -pretexto-para-no-combatir-el-cambio-climatico-ong

D’Adamo, O., Virginia, G. B., \& Flavia, F. (2007). Medios de comunicación y opinión pública. Madrid: McGraw Hill/Interamericana.

D’Hooghe, I. (2011). Europeans increasingly view China's economic rise as negative. Will public diplomacy help? Understanding China. http://www.understandingchina.eu/

Dahl-Madsen, I. (2011). Global warming, the US, and China: An analysis of US and Chinese behaviour in the climate change ... [S.l.]. Lap Lambert Academic Pub. https://www.lap-publishing.com

Dimitrov, R. S. (2010). Inside UN climate change negotiations: The Copenhagen Conference. Review of Policy Research, 27, 795-821. http://dx.doi.org/10.1111/j.1541-1338.2010.00472.x

Economy, E. (2001). The impact of international regimes on Chinese foreign policy-making: Broadening perspectives and policies...but only to a point. Palo Alto, CA: Stanford University Press.

Erhardt, L. (2012). What about brand Spain? http://www.saffron-consultants.com/our-view/what-about-brand-spai $\mathrm{n}$

Forbes (2010). Branding is key for countries.

http://www.forbes.com/2010/06/29/branding-countries-economy-bus iness-oxford-analytica.html

Freeman, D., \& Holslag, J. (2009). Climate for cooperation the EU, China and climate change. Brussels: Brussels Institute of Contemporary Chinese Studies.

Frost Randall (2004). Mapping a country's future.

http://www.brandchannel.com/features_effect.asp?pf_id=206

Galindo, C., \& Luis, J. (1998). Técnicas de investigación en sociedad, cultura y comunicación. México, etc.: Addison Wesley Longman.

GlobeScan Incorporated, \& The Program on International Policy Attitudes (PIPA) (2006). Views of China, Russia, France down sharply. http://www.globescan.com/news_archives/bbc06-3/index.html

Goodson, S. (2012). How to market an Olympic bid city or an EXPO bid city to win. New York: Forbes.

Greenpeace (2012). Doha talks fail to meet the pace of climate change. http://m.greenpeace.org/africa/en/high/News/Blog/doha-talks-fail-tomeet-the-pace-of-climate-c/blog/43349

Harris, P. G. (2010). China and climate change: From Copenhagen to Cancun. Environmental Law Reporter: News \& Analysis, 40, 1085810863.

Harris, P. G. (2011). China's responsibility for climate change: Ethics, fairness and environmental policy. Bristol: Policy Press.

Heggelund, G. (2007). China's climate change policy: Domestic and international developments. Asian Perspective, 31, 155-191.

Howes, S. (2009). Can China rescue the global climate change negotiations? China's new place in a world in crisis.

http://epress.anu.edu.au/wp-content/uploads/2011/06/ch182.pdf

HSBC Climate Change Global Research (2009). Climate change global, China's rising climate risk, the 20 questions investors need to ask. http://www.research.hsbc.com

Hsu, A., \& Kieran, C. (2009). China in Copenhagen day 5: No country is an island.

http://greenleapforward.com/2009/12/11/china-in-copenhagen-day-5no-country-is-an-island/

Interbrand (2003) Branding a country.

http://www.brandchannel.com/images/papers/country_branding.pdf

Krippendorff, K. (2004). Content analysis: An introduction to its methodology. Thousand Oaks, CA: SAGE.

Kriss, P. H., Loewenstein, G., Wang, X. H., \& Weber, R. (2011). Behind the veil of ignorance: Self-serving bias in climate change negotiation. Judgment and Decision Making, 6, 602-615.

Kyoto protocol to the United Nations framework convention on climate change. http://unfccc.int/resource/docs/convkp/kpeng.html

Leiserowitz, A. (2007). Human development report 2007/2008, fighting climate change: Human solidarity in a divided world: International public opinion, perception, and understanding of global climate change. UNDP. http://hdr.undp.org/en/reports/global/hdr2007-8/papers/leiserowitz_a nthony6.pdf.

Lewis, J. (2007). China's strategic priorities in international climate change negotiations. The Washington Quarterly Winter 2007-2008. http://muse.jhu.edu/login?auth=0\&type=summary\&url=/journals/was hington_quarterly/v031/31.1lewis.pdf

Macnamara, J. (2005). Media content analysis: Its uses, benefits and best practice methodology. Asia Pacific Public Relations Journal, 6, $1-34$.

Masters Evans Kimberly (2006). Environment: Information series on current topics. Cornell: Information Plus.

Minas, S. (2010). Foreign policy centre briefing: Crossing the riverChina in the international climate change negotiations. http://fpc.org.uk/fsblob/1315.pdf

Motaal, D. A. (2010). Negotiating with only one China on climate change: On counting ourselves lucky. Yale Journal of International Affairs, 6, 74-84.

Newbold, C. (2002). The media book. London: Arnold (Hodder Headline).

Niño-Zarazúa, M. A. (2012). Quantitative analysis in social sciences: An brief introduction for non-economists.

http://ssrn.com/abstract=2066058 http://dx.doi.org/10.2139/ssrn.2066058

Nordstrom, H. (2009). The microcosm of climate change negotiations: What can the world learn from the European Union? Geneva: ICTSD Programme on Global Economic Policy and Institutions.

Pachauri, R. K., Reisinger, A., \& IPCC (2007). Climate change 2007: Synthesis report. Contribution of working groups I, II and III to the fourth assessment report of the intergovernmental panel on climate change. Geneva: IPCC.

PBL Netherlands Environmental Assessment Agency (2011). Long-term trend in global $\mathrm{CO}_{2}$ emissions; 2011 report.

http://www.pbl.nl/en/publications/2011/long-term-trend-in-global-co 2-emissions-2011-report

People Daily (2011). Extreme weather hit China hard. http://english.peopledaily.com.cn/90001/90776/90882/7259140.html

People's Republic of China (2009). Greenhouse gas emissions reduction: A theoretical framework and global solution: Project team of the Development Research Centre of the State Council. http://www.gci.org.uk/Documents/China_Research.pdf

Reuters (2010a). China blames climate talks standoff on rich nations. http://www.mnn.com/earth-matters/climate-weather/stories/china-bla mes-climate-talks-standoff-on-rich-nations

Reuters (2010b). China says can make carbon curbs "binding”. http://www.reuters.com/article/2010/12/06/us-climate-china-idUSTR E6B55H720101206

Reuters (2012a). China climate standoff returns. http://www.reuters.com/article/2012/09/24/column-wynn-climate-un -idUSL5E8KO3N820120924

Reuters (2012b). US, China Climate Standoff Returns. http://www.smh.com.au/environment/climate-change/us-china-climat e-standoff-returns-20120925-26hxl.html

Reuters (2012c). Climate conference in Doha Stalls as US and China dig in heels.

http://uprisingradio.org/home/2012/12/04/climate-conference-in-doh a-stalls-as-us-and-china-dig-in-heels

Rivadeneira Prada, R. (1995). La opinión pública: análisis, estructura y métodos para su estudio. México: Trillas.

Ruppel, O., Grimm, S., \& Van Wyk, S. (2011). COP 17: Addressing climate change in a changed world-Chinese and African positions. Beijing: Centre for Chinese Studies.

Scientific American (2011). China may become world's biggest $\mathrm{CO}_{2}$ emitter by 2017.

http://www.scientificamerican.com/article.cfm?id=china-may-becom e-worlds-biggest-co2-2011-09

Shealy, M., James P Dorian, D. C., \& Center for Strategic and International Studies (Washington, and Energy and National Security Program (2007). Growing Chinese energy demand: Is the world in denial? Washington, DC: CSIS Press.

Siniscalco, M. T., \& Auriat, N. (2005). Questionnaire design: Quantita- 


\section{BENGUIAT}

tive research methods in educational planning. Paris: UNESCO International Institute for Educational Planning.

Song, L. G., \& Wing, T. W. (2008). China's dilemma: Economic growth, the environment and climate change. Canberra, Washington, DC, Beijing: Anu E Press, Asia Pacific Press, Brookings Institution Press, Social Sciences Academic Press (China).

Song, Y., \& Zhao, Z. Y. (2009). UNEP lauds China's commitment to combating climate change.

http://www.china-embassy.org/eng/xw/t631847.htm

Fan, G., Ackerman, F., Stern, N., Edenhofer, O., Xu, S., Eklund, K., Li, L., \& Hallding, K. (2011). The economics of climate change in China: Towards a low carbon economy. Washington, DC: Earthscan.

The Economist (2010). The European Union gets more realistic about China—and China gets more realistic about the EU. http://www.economist.com/node/15330572

The Economist (2012). Warmed-up numbers. http://www.economist.com/node/21557366

The Guardian (2009a). China blamed as anger mounts over climate deal. http://www.guardian.co.uk/environment/2009/dec/20/china-blamed-c openhagen-climate-failure

The Guardian (2009b). China tried to hijack Copenhagen climate deal. http://www.guardian.co.uk/environment/2009/dec/20/ed-miliband-ch ina-copenhagen-summit

The Guardian (2009c). Copenhagen summit: China’s quiet satisfaction at tough tactics and goalless draw.

http://www.guardian.co.uk/environment/2009/dec/20/copenhagen-cli mate-summit-china-reaction

The Guardian (2009d). The road from Copenhagen.

http://www.guardian.co.uk/commentisfree/2009/dec/20/copenhagenclimate-change-accord

The Guardian (2009e). Copenhagen treaty was "held to ransom”, says Gordon Brown.

http://www.guardian.co.uk/environment/2009/dec/21/copenhagen-tre aty-gordon-brown

The Guardian (2009f). How do I know China wrecked the Copenhagen deal? I was in the room.

http://www.guardian.co.uk/environment/2009/dec/22/copenhagen-cli mate-change-mark-lynas

The Guardian (2010). China and US blamed as climate talks stall. http://www.guardian.co.uk/environment/2010/oct/08/china-us-blame d-talks-stall

The Guardian (2012a). Doha: Climate change talks end with compensation deal for poor nations that could cost billions.

http://www.telegraph.co.uk/earth/environment/climatechange/97322 26/Doha-climate-change-talks-end-with-compensation-deal-for-poor -nations-that-could-cost-billions.html
The Guardian (2012b). China and US hold the key to a new global climate deal.

http://www.guardian.co.uk/environment/2012/dec/12/china-us-global -climate-deal

The Guardian (2013). Let’s stop hiding behind recycling and be honest about consumption.

http://www.guardian.co.uk/environment/georgemonbiot/2013/apr/12/ escalating-consumption

The New York Times (2009). Poor and emerging states stall climate negotiations.

http://www.nytimes.com/2009/12/17/science/earth/17climate.html?p agewanted=all\&_r $=0$

The New York Times (2010a). China insists that its steps on climate be voluntary.

http://www.nytimes.com/2010/01/30/world/asia/30china.html

The New York Times (2010b). China's energy use threatens goals on warming.

http://www.nytimes.com/2010/05/07/business/energy-environment/0 7energy.html?pagewanted=all

The New York Times (2012a). Climate talks yield commitment to ambitious, but unclear, actions.

http://www.nytimes.com/2012/12/09/science/earth/talks-on-climateproduce-promises-and-complaints.html

The New York Times (2012b). Doha: Weirdly tame and dispirited. http://takingnote.blogs.nytimes.com/2012/12/14/doha-weirdly-tameand-dispirited

The New York Times (2013). China and Russia block UN security council climate change action.

http://www.rtcc.org/china-and-russia-block-un-security-council-clim ate-change-action/

The Washington Post (2006). Limiting climate change: The neglected obstacle.

http://www.washingtonpost.com/wp-dyn/content/article/2006/08/17/ AR2006081701188.html

The Washington Post (1998). A/RES/43/53. http://www.un.org/documents/ga/res/43/a43r053.htm

The Washington Post (2013). Chronological evolution of the LDC work programme and introduction to the concept of NAPA. http://unfccc.int/adaptation/knowledge_resources/ldc_portal/items/47 22.php

US Congressional-Executive Commission on China (2010). Transparency in environmental protection and climate change in China. Washington, DC: US Government printing office.

Wang, T., \& Watson, J. (2009). China's energy transition: Pathways for low carbon development. Sussex: Sussex Energy Group Tyndall Centre Sussex SPRU. 